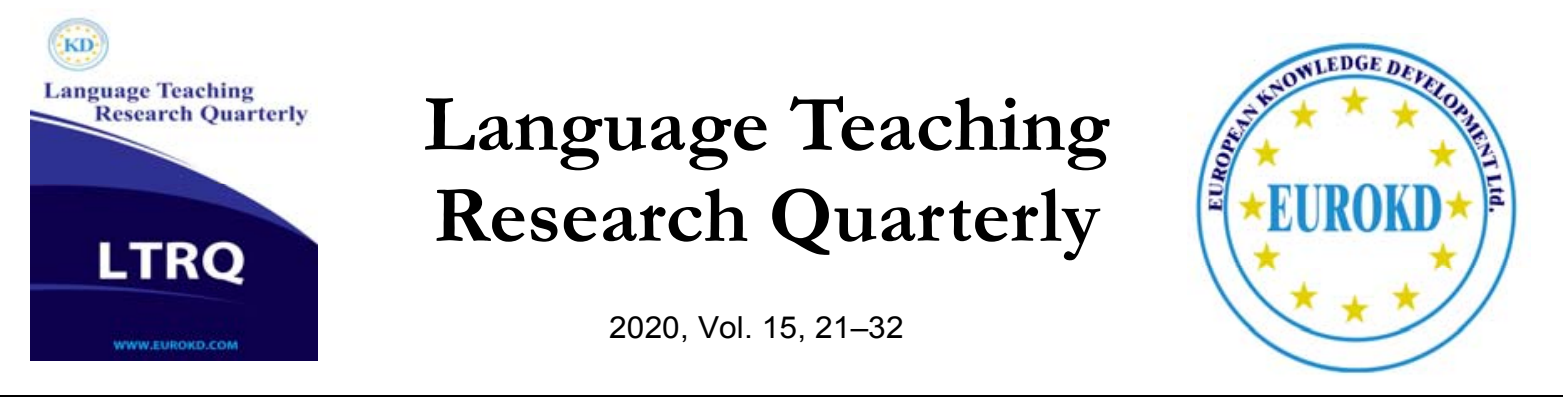

\title{
Can Vision 3 Notch up a Win over Pre- university English Textbook?
}

\author{
Mavadat Saidi*, Hanieh Mokhtarpour \\ Shahid Rajaee Teacher Training University, Tehran, Iran
}

\begin{abstract}
Future Perspectives and Challenges of Materials Development In Honor of Brian Tomlinson's Contribution to Materials Development Research
\end{abstract}

Received 01 April 2019 Accepted 29 November 2019

\begin{abstract}
The present study aimed to evaluate the newly compiled English book for the third grade of senior high school, currently called the 12th grade, and the previous English textbook for pre-university students. To this end, 80 experienced teachers, with the experience of teaching both books, were asked to complete an eclectic checklist comprising 38 items and evaluating the book in terms of nine major criteria, namely General considerations, Vocabulary, Grammar, Speaking, Listening, Reading, Writing, Pronunciation, Supplementary materials, tasks and activities. Following that, 10 teachers were also interviewed in order to deepen the quantitative data. The findings indicated that the teachers were more satisfied with the newly introduced book to the educational system. Furthermore, the mean values revealed that the teachers rated the speaking and listening sections as good or satisfactory while they ranked the supplementary materials criterion as the least satisfactory one. As regards the other criteria of the checklist, the findings demonstrated that the teachers were satisfied to some extent. In general, the results confirmed that notwithstanding the dramatic positive changes in Vision 3, it still requires to undergo major revisions in order to meet the EFL students' needs. Hence, the results would benefit the materials developers in order to locate the areas for improvement.
\end{abstract}

Keywords: Evaluation, Vision 3, Pre-university English Textbook, ELT Materials

\section{Introduction}

Textbooks play an important role in ELT curriculum (Richards, 2001) and act as a framework for both teachers and learners in the learning process (Byrd, 2001). A textbook should be selected 
wisely. Otlowski (2003) held that the textbooks should meet a wide range of the learners' needs. This necessitates evaluating its effectiveness in the teaching and learning process (McDonough \& Shaw, 2003). Despite the utmost significance of textbook evaluation, it has been highly overlooked (McGrath, 2002).

English textbooks in the mainstream education have long been compiled and developed regardless of the Iranian EFL learners' communicative needs (Ahmadisafa, Ghonchehpour, Malekmohamamdi, Seifi, \& Zekrati, 2017). However, new series of English textbooks, Prospect and Vision, have recently been developed to compensate for the shortcomings of the previous ones (Ahmadisafa et al., 2017). Most recently, Vision 3 has entered the mainstream education, intended to be used nationally for the third grade of senior high school, currently known as the $12^{\text {th }}$ grade of high school. Hence, it seems that teachers' views and experiences would provide valuable insights for improving the quality of the textbook and aligning it to the EFL students' needs.

Numerous studies have focused on evaluating the books taught in junior and senior high schools in Iran. However, since Vision 3 has just been released, no study has yet been carried out to elicit English teaches' perspectives about it. Hence, the current comparative study aimed to juxtapose Vision 3 with the previous English textbook for pre-university students to cast further light on the merits and demerits of the previously taught book and the newly developed one.

With this in mind, the present study strived to explore the English teachers' perceptions of the effectiveness of the previous English textbook for pre-university students and Vision 3 and their strengths and weaknesses.

\section{Literature Review}

The significance of textbook evaluation is an undeniable fact. A large number of scholars (Cunningsworth, 1995; Sheldon, 1995; Richards, 2001; Littlejohn, 1998; Ur, 1996) have highlighted the importance of textbook evaluation. Razmjoo (2007) stated that textbooks are the sources of comprehensible input and their role is more highlighted in EFL context since there are few opportunities for the learners to be exposed to other linguistic sources. Moreover, evaluating textbooks would lead to the constant enhancement of the quality of the textbooks. The emergence of communicative language teaching has necessitated adapting English textbooks to the new trend. It is claimed that the change has been represented in the new series of English textbooks Prospect and Vision in ELT mainstream education in Iran.

Numerous studies have been conducted to evaluate textbooks at both national and international level. Litz (2005) evaluated a textbook taught in South Korean universities and pointed to the significance of this book and its merits. Iraji (2007) attempted to see if Interchange series followed TBLT and CLT principles and found out that despite their reputation as the most efficient books in terms of teaching English methodology, they were not completely in line with the principles underlying TBLT and CLT. Tok (2010) evaluated an English textbook Spot On which is taught in Turkey considering the general layout, activities and exercises, subjects and skills, and concluded that the book was not appropriate for the Turkish mainstream education. 
Furthermore, Juan (2010) evaluated English College taught in universities in China. The book was considerate of the cultural points in its activities and texts. However, it performed weakly in presenting adequate information about different cultures. In another study, Ahmadisafa, Moradi, and Hamzavi (2015) evaluated Top Notch series from the teachers' and learners' perspectives and concluded that they were quite content with the books considering their potential to enhance the learners' intercultural competence.

At the national scale, the books taught in ELT curriculum in schools have been widely evaluated. Jahangard (2007) evaluated several books taught in Iranian high schools and pointed to a number of merits, namely including challenging and interesting topics. However, he referred to lack of adequate attention to the speaking skill as a weakness in these books. Bemani and Jahangard (2014) analyzed Prospect 1 (the book taught in the first grade of junior high school) from teachers' perspectives and concluded that the book could meet the teachers' expectations to some extent while it needed serious modifications in terms of different skills and cultural issues. Ahmadi and Derakhshan (2014) also evaluated Prospect 1 from English teachers' perspectives and found out that most teachers held positive views towards the book with regard to the speaking and listening skills and had negative views considering the allocated time to the book and lack of attention to the reading and writing skills. Ahmadisafa and Farahani (2016) also pointed to the weak performance of Prospect 1 considering the development of intercultural competence.

In a relevant study to the current one, Jamalvandi (2014) attempted to evaluate the English textbook for pre-university students. The findings showed that more than half of the teachers believed that the book could meet the real needs of the learners moderately. However, they mostly refereed to the inadequacy of the presentation of culture. Previous versions of the textbook for pre-university applicants (currently the third grade of senior high school) have been commonly reported to suffer from numerous shortcomings (Amini \& Birjandi, 2012; Yarmohammadi, 2002).

Taking into account the fact that Vision 3 has been recently compiled and added to the educational system, the current study aimed to compare it with the previous English textbook for pre-university students to unravel the major revisions it had and the weak points to be overcome.

\section{Method \\ Participants}

The participants of the present study consisted of 80 English teachers in the third grade of senior high school (so-called $12^{\text {th }}$ grade). Adopting convenient sampling, the teachers, with 5 to 15 years of teaching experience, were selected. The participants were teaching the newly published book and have been teaching the previous English textbook for pre-university students. Hence, they had the experience of teaching both books under the study. Their age ranged from 27 to 52 and they held BA (56), MA (21), and PhD (3) degrees in Teaching English as a Foreign Language (TEFL) (57), English Literature (13), and English Translation (10). 


\section{Instrumentation}

The eclectic checklist developed and applied in Shahmohammadi (2018) was used consisting of ten subcategories, namely General, Vocabulary, Grammar, Speaking, Listening, Writing, Reading, Pronunciation, Supplementary materials and tasks, and Activities. The checklist included 38 items scaled from Poor (1), Fair (2), Good (3), and Excellent (4). It was given to three PhD holders in TEFL with more than 10 years of teaching and researching experiences to be checked for its validity. Moreover, Cronbach alpha was calculated as 0.89 to check its reliability. Moreover, an unstructured interview was also conducted with the English teachers in order to elicit their comments on the newly developed English textbook and enrich the quantitative data.

\section{Data Collection and Analysis}

The checklist was given to the teachers through email or social media. They were asked to complete the checklist and express their agreement to participate in the unstructured interview. A total of 80 English teachers completed the questionnaire and 10 teachers were interviewed. They were asked to comment on different parts of the old and new textbooks and present their suggestions for improving the quality of the textbook. The mean values for each item and criterion were calculated. The results are presented in next section.

\section{Results and Discussion}

The findings of the study are presented for each subcategory of the checklist for both Vision 3 and the previous English textbook for pre-university students.

\section{General Considerations}

The first criterion was general considerations. The results indicated that the teachers were satisfied with the directions for presentation of language items in the newly published book while they were more satisfied with the cultural sensitivity considered in pre-university textbook. In general, they were more satisfied with the general considerations in the newly developed textbook, Vision 3.

Table 1

Descriptive Statistics for General Considerations

\begin{tabular}{|c|c|c|c|c|}
\hline Items & $\begin{array}{c}\text { Mean } \\
\text { Vision } 3\end{array}$ & $\begin{array}{l}\text { Mean } \\
\text { Pre-university }\end{array}$ & $\begin{array}{l}\text { Mean of the } \\
\text { Criteria For } \\
\text { Vision } 3\end{array}$ & $\begin{array}{l}\text { Mean of the } \\
\text { Criteria for } \\
\text { Pre-university }\end{array}$ \\
\hline $\begin{array}{l}\text { The textbook takes into account the current accepted } \\
\text { methods of ESL/EFL. }\end{array}$ & 2.2 & 1.55 & \multirow{5}{*}{2.92} & \multirow{5}{*}{1.64} \\
\hline It gives directions for presentation of language items. & 3.4 & 1.32 & & \\
\hline It relates content to the learner's culture and context. & 3.05 & 1.85 & & \\
\hline Cultural sensitivity has been considered. & 3.15 & 2.1 & & \\
\hline It has authentic and real use of language. & 2.8 & 1.4 & & \\
\hline
\end{tabular}


The findings showed that the teachers claimed that the newly developed book took account of the current teaching methods more than its previous counterpart. Moreover, the book seemed to gear more to the learner's culture and context in Vision 3. Furthermore, the teachers believed that Vision 3 included more authentic and real samples of language use. These all showed that Vision 3 could be considered as the modified version of the previously taught book.

\section{Vocabulary}

The second criterion was related to the presentation of vocabulary in two book series. As Table 2 displays, the teachers were mostly satisfied with the selection of the vocabulary in Vision 3 while they held consensus over the appropriate load of vocabulary in pre-university English textbook.

However, it seems that English teachers believed that the distribution of words across chapters and the whole book and their presentation in contexts and situations were not satisfactory in Vision 3 while they thought that the words were not repeated and recycled in preuniversity English textbook as well. In general, the English teachers were satisfied with the vocabulary sections in Vision 3 more than that of the previously taught textbook.

Table 2

Descriptive Statistics for Vocabulary

\begin{tabular}{|c|c|c|c|c|}
\hline Items & $\begin{array}{l}\text { Mean } \\
\text { Vision } 3\end{array}$ & $\begin{array}{l}\text { Mean } \\
\text { Pre-university }\end{array}$ & $\begin{array}{ll}\text { Mean of the } \\
\text { Criteria } & \text { For } \\
\text { Vision } 3 & \\
\end{array}$ & $\begin{array}{l}\text { Mean of the } \\
\text { Criteria for } \\
\text { Pre-university }\end{array}$ \\
\hline $\begin{array}{l}\text { It presents vocabulary in appropriate contexts } \\
\text { and situations. }\end{array}$ & 2.5 & 2.05 & \multirow{5}{*}{2.91} & \multirow{5}{*}{2.36} \\
\hline $\begin{array}{l}\text { The selection of the vocabulary is based on } \\
\text { specified criteria. }\end{array}$ & 3.4 & 2.55 & & \\
\hline $\begin{array}{l}\text { Load of vocabulary is appropriate to the level of } \\
\text { learners. }\end{array}$ & 3.1 & 3.05 & & \\
\hline $\begin{array}{l}\text { Words are efficiently repeated and recycled } \\
\text { across the book. }\end{array}$ & 3.1 & 1.6 & & \\
\hline $\begin{array}{l}\text { Distribution of the vocabulary across chapters } \\
\text { and the whole book is good. }\end{array}$ & 2.45 & 2.55 & & \\
\hline
\end{tabular}

\section{Grammar}

As Table 3 shows, the teachers mostly agreed that the grammar sections in Vision 3 provides adequate models of the target structures while they were not satisfied with the incidental reworking of the structures. Likewise, they thought that grammar sections in previous textbook could also provide sufficient models of the grammatical structures and lacked enough sections for recycling the grammatical points. Although English teachers preferred the grammar sections in Vision 3, they held somehow negative attitudes towards this criterion in both books. It seems that more emphasis should still be put on developing communicative competence when grammatical structures are presented. 
Table 3

Descriptive Statistics for Grammar

\begin{tabular}{|c|c|c|c|c|}
\hline Items & $\begin{array}{c}\text { Mean } \\
\text { Vision } 3\end{array}$ & $\begin{array}{c}\text { Mean } \\
\text { Pre-university }\end{array}$ & $\begin{array}{c}\text { Mean of the } \\
\text { Criteria } \\
\text { For Vision } 3\end{array}$ & $\begin{array}{l}\text { Mean of the } \\
\text { Criteria for Pre- } \\
\text { university }\end{array}$ \\
\hline $\begin{array}{l}\text { It stresses communicative competence in } \\
\text { teaching structural items. }\end{array}$ & 2.5 & 1.55 & \multirow{4}{*}{2.22} & \multirow{4}{*}{1.75} \\
\hline $\begin{array}{l}\text { It provides adequate models featuring the } \\
\text { structure to be taught. }\end{array}$ & 2.7 & 2.35 & & \\
\hline Grammar is contextualized. & 2.15 & 1.75 & & \\
\hline $\begin{array}{l}\text { Grammar is introduced explicitly and reworked } \\
\text { incidentally throughout the book. }\end{array}$ & 1.55 & 1.35 & & \\
\hline
\end{tabular}

\section{Speaking}

The fourth subcategory of the checklist was speaking section. As Table 4 illustrates, speech situations related to the learners' background knowledge was the criterion with the highest degree of satisfaction among the English teachers for both books. However, the findings showed that the teachers were more satisfied with the speech situations in Vision 3. In general, teachers perceived Vision 3 as a more appropriate book than the previous one in terms of the speaking skill tasks and activities. Nevertheless, they believed that the tasks are not sufficient in this book.

Table 4

Descriptive Statistics for Speaking

\begin{tabular}{|c|c|c|c|c|}
\hline Items & $\begin{array}{c}\text { Mean } \\
\text { Vision } 3\end{array}$ & $\begin{array}{c}\text { Mean } \\
\text { Pre-university }\end{array}$ & $\begin{array}{c}\text { Mean of the } \\
\text { Criteria } \\
\text { For Vision } 3\end{array}$ & $\begin{array}{l}\text { Mean of the } \\
\text { Criteria for Pre- } \\
\text { university }\end{array}$ \\
\hline $\begin{array}{l}\text { Speaking tasks are complete, appropriate, and } \\
\text { adequate. }\end{array}$ & 2.65 & 1.7 & \multirow{3}{*}{3.06} & \multirow{3}{*}{1.65} \\
\hline $\begin{array}{l}\text { It includes speech situations relevant to the } \\
\text { learners' background. }\end{array}$ & 3.35 & 1.85 & & \\
\hline $\begin{array}{l}\text { The speaking activities are developed to initiate } \\
\text { meaningful communication. }\end{array}$ & 3.2 & 1.4 & & \\
\hline
\end{tabular}

\section{Listening}

With regard to the listening skill, the results demonstrated that the teachers agreed that listening tasks were presented taking into account their degree of difficulty in both books. However, the teachers seem to be more satisfied with the listening sections in Vision 3. Indeed, the separate parts allocated to developing this skill were rated as more satisfactory in Vision 3 than those of previous English textbook. 
Table 5

Descriptive Statistics for Listening

\begin{tabular}{lcccc}
\hline Items & $\begin{array}{c}\text { Mean } \\
\text { Vision 3 }\end{array}$ & $\begin{array}{c}\text { Mean } \\
\text { Pre-university }\end{array}$ & $\begin{array}{c}\text { Mean of the } \\
\text { Criteria } \\
\text { For Vision 3 }\end{array}$ & $\begin{array}{c}\text { Mean of the } \\
\text { Criteria for } \\
\text { Pre-university }\end{array}$ \\
$\begin{array}{l}\text { The tasks for listening are arranged from simple to } \\
\text { complex. }\end{array}$ & 3.15 & 2.7 & & 2.1 \\
\hline \begin{tabular}{l} 
The tasks are authentic. \\
\hline
\end{tabular} & 2.95 & 1.5 & 3.05 & 2.1 \\
\hline
\end{tabular}

\section{Writing}

Considering the writing skill, the teachers were mostly satisfied with the controlled and guided practice in writing sections. However, they evaluated the writing section in Vision 3 more satisfactory. Indeed, the teachers believed that the newly published book represented a dramatic improvement in developing the students' writing skill. Still, they were not quite satisfied with the lack of relevance of the writing tasks to the students' interest and context.

Table 6

Descriptive Statistics for Writing

\begin{tabular}{lcccc}
\hline Items & $\begin{array}{c}\text { Mean } \\
\text { Vision 3 }\end{array}$ & $\begin{array}{c}\text { Mean } \\
\text { Pre-university }\end{array}$ & $\begin{array}{c}\text { Mean of } \\
\text { the Criteria } \\
\text { For Vision 3 }\end{array}$ & $\begin{array}{c}\text { Mean of the } \\
\text { Criteria for } \\
\text { Pre-university }\end{array}$ \\
\hline $\begin{array}{l}\text { The written tasks are related to the structure and } \\
\text { vocabulary practiced orally. }\end{array}$ & 3 & 1.5 & \multirow{2}{*}{2.91} & 1.48 \\
$\begin{array}{l}\text { They give practice in controlled and guided } \\
\text { composition in early stages. }\end{array}$ & 3.4 & 1.7 & \\
$\begin{array}{l}\text { They relate learning to the learners' interest and } \\
\text { context. }\end{array}$
\end{tabular}

\section{Reading}

With regard to the reading skill, the teachers seem not to be quite satisfied in both books. Although the teachers believed that the tasks could better check the students' understanding of plain sense and implied meaning in Vision 3, they thought that the book needed major modifications to cover a variety of styles and text types.

Table 7

Descriptive Statistics for Reading

\begin{tabular}{lcccc}
\hline Items & $\begin{array}{c}\text { Mean } \\
\text { Vision 3 }\end{array}$ & $\begin{array}{c}\text { Mean } \\
\text { Pre-university }\end{array}$ & $\begin{array}{c}\text { Mean of the } \\
\text { Criteria } \\
\text { For Vision 3 }\end{array}$ & $\begin{array}{c}\text { Mean of the } \\
\text { Criteria for Pre- } \\
\text { university }\end{array}$ \\
\hline $\begin{array}{l}\text { Reading tasks offer exercises for understanding of } \\
\text { plain sense and implied meaning. }\end{array}$ & 3.65 & 2.65 & & 2.73 \\
$\begin{array}{l}\text { It selects passages within the vocabulary range of } \\
\text { the students. }\end{array}$ & 2.7 & 2.5 & & 2.5 \\
$\begin{array}{l}\text { It selects passages reflecting a variety of style of } \\
\text { contemporary English. }\end{array}$ & 1.85 & 2.35 & & \\
\hline
\end{tabular}




\section{Pronunciation}

Considering pronunciation, the findings indicated that the teachers believed that the presentation of pronunciation features improved to a great extent in the newly published book. They were also quite satisfied with the exercises on stress patterns and intonation. However, they thought that the book needs major modifications with regard to the exercises for reinforcing individual sounds. In general, the results showed that the teachers rated Vision 3 higher than previous English textbook for pre-university students in terms of pronunciation.

Table 8

Descriptive Statistics for Pronunciation

\begin{tabular}{|c|c|c|c|c|}
\hline Items & $\begin{array}{c}\text { Mean } \\
\text { Vision } 3\end{array}$ & $\begin{array}{l}\text { Mean } \\
\text { Pre-university }\end{array}$ & $\begin{array}{c}\text { Mean of the } \\
\text { Criteria } \\
\text { For Vision } 3\end{array}$ & $\begin{array}{l}\text { Mean of the } \\
\text { Criteria for } \\
\text { Pre-university }\end{array}$ \\
\hline The presentation is complete and appropriate. & 3.35 & 1.75 & \multirow{4}{*}{2.35} & \multirow{4}{*}{1.43} \\
\hline $\begin{array}{l}\text { There is a sufficient exercise on recognition and } \\
\text { production of individual sound. }\end{array}$ & 1.45 & 1.5 & & \\
\hline $\begin{array}{l}\text { There is a sufficient exercise on recognition and } \\
\text { production of stress patterns. }\end{array}$ & 2.15 & 1.25 & & \\
\hline $\begin{array}{l}\text { There is a sufficient exercise on recognition and } \\
\text { production of intonation. }\end{array}$ & 2.45 & 1.25 & & \\
\hline
\end{tabular}

\section{Supplementary Materials}

As Table 9 shows, the teachers were satisfied with the workbook and supplementary activities provided for both books. However, it seems more satisfactory in the newly published book. However, the results indicated that supplementary materials still need further modification to meet the teachers' expectations. In this regard, the books should be improved in terms of the visual elements and teacher's manual.

Table 9

Descriptive Statistics for Supplementary Materials

\begin{tabular}{|c|c|c|c|c|}
\hline Items & $\begin{array}{c}\text { Mean } \\
\text { Vision } 3\end{array}$ & $\begin{array}{c}\text { Mean } \\
\text { Pre-university }\end{array}$ & $\begin{array}{c}\text { Mean of } \\
\text { the Criteria } \\
\text { For Vision } 3\end{array}$ & $\begin{array}{l}\text { Mean of the } \\
\text { Criteria for } \\
\text { Pre-university }\end{array}$ \\
\hline $\begin{array}{l}\text { The book contains visual materials such as pictures, } \\
\text { videos, flash cards. }\end{array}$ & 1.55 & 1.3 & \multirow{4}{*}{1.9} & \multirow{4}{*}{1.55} \\
\hline It contains audio/video material. & 1.85 & 1.3 & & \\
\hline $\begin{array}{l}\text { The teacher guide is available and gives useful and } \\
\text { complete guidance along with alternative activities. }\end{array}$ & 1.75 & 1.5 & & \\
\hline $\begin{array}{l}\text { The book has work book and supplementary } \\
\text { activities. }\end{array}$ & 2.45 & 2.1 & & \\
\hline
\end{tabular}

\section{Tasks and Activities}

As Table 10 displays, the teachers stated that the activities better catered to the learners' success in communication through making a balance between controlled and free tasks and activities in Vision 3 than previous textbook for pre-university students. The teachers thought that the new 
book should still be improved in terms of interesting and adequate activities. Although the activities in Vision 3 were more satisfactory than those of previous English textbook for preuniversity students from teachers' perspectives, several revisions should be made.

Table 10

Descriptive Statistics for Tasks and Activities

\begin{tabular}{|c|c|c|c|c|}
\hline Items & $\begin{array}{c}\text { Mean } \\
\text { Vision } 3\end{array}$ & $\begin{array}{l}\text { Mean } \\
\text { Pre-university }\end{array}$ & $\begin{array}{l}\text { Mean of the } \\
\text { Criteria } \\
\text { For Vision } 3\end{array}$ & $\begin{array}{l}\text { Mean of the } \\
\text { Criteria for } \\
\text { Pre-university }\end{array}$ \\
\hline The activities are interesting and adequate. & 1.45 & 1.18 & \multirow{5}{*}{2.59} & \multirow{5}{*}{1.54} \\
\hline $\begin{array}{l}\text { The activities are designed so that the learners are } \\
\text { using language rather than just practicing specified } \\
\text { features of it. }\end{array}$ & 2.85 & 1.75 & & \\
\hline $\begin{array}{l}\text { The activities help learners to communicate } \\
\text { fluently, accurately, appropriately, and effectively. }\end{array}$ & 2.85 & 1.25 & & \\
\hline $\begin{array}{l}\text { There is a balance between controlled and free } \\
\text { activities. }\end{array}$ & 3.1 & 1.5 & & \\
\hline $\begin{array}{l}\text { The activities and exercises are varied in format so } \\
\text { that they will continually motivate and challenge } \\
\text { learners. }\end{array}$ & 2.7 & 1.4 & & \\
\hline
\end{tabular}

\section{Results of the Unstructured Interview}

To enrich the quantitative phase of the study, 10 teachers were also interviewed. They were asked to provide their recommendations for improving the quality of the book.

The teachers stated that the textbooks did not accompany a CD Rom and the audio files were not easily accessible. They said that they could access the audio files through informal channels. They also believed that although the book improved in terms of the skills and sub-skills, it still needs to be revised. In this regard, more authentic and real samples of language use from the contemporary English should be included. Moreover, they held that the number of activities should be increased and more tailed to the learners' interest.

On the other hand, the teachers thought that these two books have reading-based approach which is in line with the macro policies which tend to prepare high school students to enter university and read academic texts. In this sense, both books are aligned to the students' needs. However, they mentioned that the presented set of vocabulary should be contextualized, welldistributed, and recycled within the textbook.

The teachers also pinpointed that even the new book lacks flexibility. Since it is used all around the country in different regions with different resources and facilities, the teachers thought that the book does not allow the teachers to adapt the content and activities to the students' background and context. Some interviewees also pointed to the significance of holding in-service workshops for the teachers in order to equip them with pedagogical resources and professional understanding. 


\section{Discussion}

The study aimed to investigate the strengths and weaknesses of Vision 3 and previous English textbook for pre-university students from English teachers' perspectives. The findings indicated that the newly compiled book underwent considerable modification and improved in terms of all subcategories of the checklist. The teachers believed that Vision 3 had most revisions regarding the speaking and listening skills while they were not satisfied with its supplementary materials.

The findings showed that the teachers were satisfied with several features in Vision 3, namely giving directions for presentation of language items, selecting words based on specified criteria, presenting adequate models for the grammatical structures, relating the speaking tasks to the students' background, including controlled and free composition exercises, presenting exercises for understanding plain sense or implied meaning, giving a complete presentation of pronunciation features, provisioning workbook and a balanced set of free and controlled exercises.

However, the teachers believed that the book should still work for aligning itself to the current teaching methods. The book should include more authentic samples and provide more appropriate contexts for teaching words. It should also contextualize the grammatical structures and provide a recycling account of the presented words and structures. They also held that Vision 3 should include sufficient speaking tasks and more authentic listening exercises. The teachers also stated that the book needs to be enriched by adding a variety of styles of contemporary English. Furthermore, they thought that Vision 3 should be revised through including more exercises for individual sounds and interesting and adequate activities on other aspects of language. They also were critical of the lack of sufficient visual elements and difficulty in accessing the teacher guide.

The results of the current study showed that English teachers were more satisfied with the newly compiled book for the students at the last grade of high school than the previous English textbook for pre-university students. The findings were in line with those of other studies in which the teachers favored the newly published books in terms of content (Salehi \& Amini, 2016; Torki \& Chalak, 2017). However, the results contrasted those of previous studies which highlighted the lack of attention to different skills and sub-skills (Jahangard, 2007; Moghtadi, 2014; Torki \& Chalak, 2017).

The results also were in contrary with those of Rashid and Kehtarfard (2014)'s study which confirmed that the textbooks do not cover important components of language. However, it seems necessary to make revisions to improve the quality of these sections so that they meet the learners' needs in the current world. Nevertheless, they were in line with their findings about supplementary materials in that they need further modification. However, most of the previously conducted studies on new series of English textbooks, namely Prospect were akin to the findings of the present study in that the new generation of English textbooks are conceived as more effective and appealing compared to their preceding ones (Shahmohammadi, 2018). However, they could meet the students' needs at an average level and are still in need of major revisions (Jamalvandi, 2014). 


\section{Conclusion}

The findings of the study demonstrated that the newly compiled book is more favored by English teachers compared to its predecessors. However, the subcategories were not rated as satisfactory or good except for the listening and speaking skills. Most subcategories, including general considerations, vocabulary, grammar, reading, writing, pronunciation, tasks and activities, were rated as fair. It might imply that these sections also need modifications and revisions. Furthermore, the teachers believed that supplementary materials are ranked as almost fair.

These all indicate that not belittling the positive changes in the new version of the book for the last grade of high school, the book still requires major revisions to meet the learners' needs. In this regard, presenting a larger number of activities related to the real-life use of language is a must to enable the students to take advantage of their linguistic knowledge for meaningful communication.

The findings of the present study would benefit the authors of the newly compiled book to adapt and revise it in order to better cater to the students' needs. In addition, it is recommended to hold several meetings, workshops, and seminars to elicit the book real users', teachers' and students', comments and criticisms when a new book is introduced to the mainstream education in order to augment the effectiveness and practicality of the book. In this line, further studies can delve into the factors which might influence the teachers' and learners' evaluation of ELT materials in schools. Moreover, the content and activities of the book can be fully and more precisely analyzed to unfold the strengths and shortcomings in order to revise them for the better.

"This work was supported by Shahid Rajaee Teacher Training University under contract number 23110."

\section{References}

Ahmadi, A., \& Derakhshan, A. (2016). EFL teachers' perceptions towards textbook evaluation. Theory and Practice in Language Studies, 6(2), 260-267.

Ahmadisafa, M., \& Farahani, M. (2016). Developing intercultural competence in Prospect 1 from EFL teachers' perspectives. Critical Studies in Texts and Programs of Human Sciences, 15 (36), 1-24.

Ahmadisafa, M., Ghonchehpour, A., Malekmohammadi, R., Seifi, Z., \& Zekrati, S. (2017). Textbook evaluation of Prospect 2 from teachers' perspectives. Journal of Language Research, 9 (24), 7-32.

Ahmadisafa, M., Moradi, M., \& Hamzavi, R. (2015). "Iranian EFL Teachers and Learners Perspective on Potentiality of Top Notch Series for Intercultural Competence Development". Iranian Journal of Language Teaching Research, 3(2), 47-66.

Amini, M., \& Birjandi, P. (2012). Gender bias in the Iranian high school EFL textbooks. English Language Teaching, 5 (2), 134-147.

Bemani, M, \& Jahangard, A. (2014). "Attitude Analysis of Teachers: The Case of Iranian Newly Developed EFL Textbook for Junior High Schools". International Journal of Language Learning and Applied Linguistics World, $7(1), 198-215$.

Byrd, P. (2001). Textbooks: evaluation for selection and analysis for implementation. Teaching English as a Second or Foreign Language, 3, 415-427.

Cunningsworth, A. (1995). Choosing your coursebook: choosing your coursebook. Oxford: Heinemann. 
Iraji, A. (2007). Pragmatic features of the New Interchange: How communicative and task-based is it? Unpublished Master's Thesis, Shiraz University, Iran.

Jahangard, A. (2007). Evaluation of EFL materials taught at Iranian public high schools. The Asian EFL Journal, 9 (2), 130-150.

Jamalvandi, B. (2014). ELT textbook evaluation in Iran, new insights. European Online Journal of Natural and Social Sciences, 3 (4), 1068-1078.

Juan, R. (2010). A content analysis of the cultural content in the EFL textbooks. Canadian Social Science, 6 (5), 137-144.

Littlejohn, A. (1998). The analysis of language teaching materials: Inside the Trojan Horse. Materials Development in Language Teaching, 190-216.

Litz, D. R. A. (2005). Textbook evaluation and ELT management: A South Korean case study. Asian EFL Journal. Retrieved June 2018 from http://www.asian-efljournal.com/Litz thesis.pdf.

McDonough, J., \& Shaw, C. (2003). Materials and Methods in ELT. Oxford: Blackwell Publishers.

McGrath, I. (2002). Materials evaluation and design for language teaching. Edinburg: Edinburg University Press.

Moghtadi, L. (2014). Iranian high school EFL textbooks. Why they should be modified. International Journal of Language Learning and Applied Linguistics World, 5(2), 53-69.

Otlowski, M. (2003). Ethnic diversity and gender bias in EFL textbooks. Asian EFL Journal, 5 (2), 1-15.

Rashid, N., \& Kehtarfard, R. (2014). A needs analysis approach to the evaluation of Iranian third-grade highs school English textbook. Sage Open, 1-9.

Razmjoo, S. A. (2007). High schools or private institutes' textbooks? Which fulfill communicative language teaching principles in the Iranian context. Asian EFL Journal, 9 (4), 126-140.

Richards, J. C. (2001). Curriculum development in language teaching. Ernst KlettSprachen.

Salehi, H., \& Amini, M. (2016b). Teachers' perceptions of the new English textbook named Prospect 1 used in Iranian junior high schools. Modern Journal of Language Teaching Methods, 6(6), 407-416.

Shahmohammadi, S. (2018). Textbook evaluation: looking at Prospect series through teachers' perspective. Research in English Language Pedagogy, 6 (2), 182-2014.

Sheldon, L. E. (1988). Evaluating ELT textbooks and materials. ELT Journal, 42 (4), 237-246.

Tok, H. (2010). TEFL textbook evaluation: from teachers' perspectives. Educational Research and Review, 5 (9), 508-517.

Torki, F., \& Chalak, A. (2017). An evaluation of English textbooks used in Iranian high schools: teachers' and learners' attitudes. Research in English Language Pedagogy, 5(1), 52-60.

Ur, P. (1996). A course in language teaching: practice and theory. Cambridge: Cambridge University Press.

Yarmohammadi, L. (2002). The evaluation of pre-university textbooks. The Newsletter of the Iranian Academy of Science, 18, 70-87. 